\title{
Organic and inorganic fertilization on the yield and quality of soybean
}

\author{
S. Khaim, M. A. H. Chowdhury* and B. K. Saha \\ Department of Agricultural Chemistry, Bangladesh Agricultural University, Mymensingh-2202, Bangladesh \\ *E-mail: akhterbau11@gmail.com
}

\begin{abstract}
Combined application of organic and inorganic fertilizers can play an important role for increasing yield and quality of soybean. Therefore, a field experiment was conducted at Genetics and Plant Breeding farm, Bangladesh Agricultural University from July to November, 2011 to evaluate the effect of cowdung and poultry manure with chemical fertilizer on the yield and quality of soybean cv. BINA soybean-2. The experiment was laid out in randomized complete block design having 9 treatments viz. control (CT), 100\% recommended dose of chemical fertilizers (RDCF $100 \%)$, 50\% RDCF (RDCF $50 \%)$, cowdung $10 \mathrm{t} \mathrm{ha}^{-1}\left(\mathrm{CD}_{10} \mathrm{tha}^{-1}\right), 50 \%$ RDCF + CD $5 \mathrm{t} \mathrm{ha}^{-1}\left(\mathrm{RDCF}_{50 \%}+\mathrm{CD}_{5} \mathrm{tha}^{-1}\right), 75 \% \mathrm{RDCF}+\mathrm{CD}_{3}$ $\mathrm{t} \mathrm{ha}^{-1}\left(\mathrm{RDCF}_{75 \%}+\mathrm{CD}_{3} \mathrm{t} \mathrm{ha}^{-1}\right)$, poultry manure $3 \mathrm{t} \mathrm{ha}^{-1}\left(\mathrm{PM}_{3 \mathrm{tha}}{ }^{-1}\right), 50 \%$ RDCF + PM $1.5 \mathrm{t} \mathrm{ha}^{-1}\left(\mathrm{RDCF}_{50 \%}+\mathrm{PM}_{1.5 \mathrm{tha}}{ }^{-1}\right)$ and $75 \%$ RDCF + PM $1 \mathrm{t} \mathrm{ha}^{-1}\left(\mathrm{RDCF}_{75 \%}+\mathrm{PM}_{1 \mathrm{t} \mathrm{ha}}{ }^{-1}\right)$ with 3 replications. All the treatments significantly influenced the yield, yield attributing parameters and protein content except oil content of BINA soybean-2. The highest plant height, yield, branches plant ${ }^{-1}$, filled pods plant ${ }^{-1}$, grain plant ${ }^{-1}$ and 100 -grain wt. were found in RDCF $_{100 \%}$, which were statistically identical with $\mathrm{RDCF}_{75 \%}+\mathrm{PM}_{1 \mathrm{tha}}{ }^{-1}$ and $\mathrm{RDCF}_{75 \%}+\mathrm{CD}_{3}$ tha ${ }^{-1}$ and the lowest values of all the parameters were obtained from control treatment. The maximum protein content was observed in RDCF $100 \%$, which was identical to $\mathrm{RDCF}_{75 \%}+\mathrm{PM}_{1 \mathrm{tha}}{ }^{-1}$ and $\mathrm{RDCF}_{75 \%}+\mathrm{CD}_{3 \mathrm{tha}}{ }^{-1}$ and the lowest value was found in control. The overall finding of this study indicated that organic manure in combination with the recommended dose of chemical fertilizers can be applied to achieve better yield and quality of soybean as well as to improve soil fertility status.
\end{abstract}

Keywords: Soybean, Organic and inorganic fertilizers, Yield, Protein, Oil contents

\section{Introduction}

Soybean is one of the most important oil seed crop in the world. Oil and protein rich soybean has now been recognized all over the world as a potential supplementary source of edible oil and nutrition (Kaul and Das, 1986). The oil of soybean contains $85 \%$ unsaturated fatty acid and is cholesterol free. Soybean seeds contain $43.2 \%$ protein, $19.5 \%$ fat, $20.9 \%$ carbohydrate and a good amount of other nutrients like calcium, phosphorus, iron and vitamins (Gopalan et al., 1971; Rahman, 1982). Soybean has 3\% lecithin which is helpful for brain development. For the agricultural development, fertilizer management is an important factor. Now-a-day, farmers are more interested to use chemical fertilizers, as a result the use of manure is decreasing in the agricultural practices of Bangladesh. Ultimately the effect of chemical fertilizer is not so good. The continuous use of high level of chemical fertilizers has led to problem of soil degradation, which is proving detrimental to crop production in our country. So we need balanced fertilization for crop production. But combined application of manure may reduce the need for chemical fertilizer, allowing the small farmers to save a part of the cost of production. In addition, global environment pollution can be controlled considerably by reducing the use of chemical fertilizer and increasing the use of manures. So, application of chemical fertilizer in combination with bio-fertilizer, cowdung (CD) and poultry manure (PM) may increase the yield and yield contributing characters such as number of pods, 100-seed weight, grain yield, straw yield and biological yield, hence ultimately resulting in increased productivity of soybean (Shirpukar et al., 2006).

The addition of manures combined with chemical fertilizers could be a promising technique to increase the crop production of soybean. Therefore, adequate and balanced application of organic and inorganic fertilizers is necessary to increase productivity and soil fertility. Moreover, the addition of manures to soil may also increase the fertilizer-use efficiency, stimulate the proliferation of diverse group of soil microorganisms and play an important role in the maintenance of ecological balance of rhizosphere. Therefore, the study was conducted to find out the suitable combination of organic and inorganic fertilizers in order to obtain better yield and quality of soybean cv. BINA soybean -2 .

\section{Materials and Methods}

A field study was carried out at the experimental farm of the Department of Genetics and Plant Breeding, Bangladesh Agricultural University, Mymensingh during the period from July to November, 2011. Initial soil sample was collected and kept in a polyethylene bag for chemical analysis. The soil was analyzed 
following the standard methods (Page et al., 1982). The soil was silt loam in texture having $\mathrm{pH} 6.72$ with $0.34 \%$ organic carbon, $0.09 \% \mathrm{~N}, 19.67 \mu \mathrm{g} \mathrm{g}^{-1} \mathrm{P}, 4.38 \mu \mathrm{g} \mathrm{g}^{-1} \mathrm{~S}$ and $0.17 \mathrm{cmol} \mathrm{kg}^{-1} \mathrm{~K}$. Seeds were collected from the BINA, Mymensingh. There were 9 treatment combinations of organic and inorganic fertilizers viz. control (CT), 100\% recommended dose of chemical fertilizers (RDCF $100 \%$ ), 50\% RDCF $\left(\mathrm{RDCF}_{50 \%}\right)$, cowdung $10 \mathrm{t} \mathrm{ha}^{-1}\left(\mathrm{CD}_{10} \mathrm{tha}^{-1}\right), 50 \% \mathrm{RDCF}+\mathrm{CD} 5 \mathrm{tha}^{-1}\left(\mathrm{RDCF}_{50 \%}+\mathrm{CD}_{5} \mathrm{tha}^{-1}\right), 75 \% \mathrm{RDCF}+$ CD $3 \mathrm{t} \mathrm{ha}^{-1}\left(\mathrm{RDCF}_{75 \%}+\mathrm{CD}_{3} \mathrm{tha}^{-1}\right)$, poultry manure $3 \mathrm{t} \mathrm{ha}^{-1}\left(\mathrm{PM}_{3} \mathrm{t} \mathrm{ha}^{-1}\right), 50 \%$ RDCF $+\mathrm{PM} 1.5 \mathrm{t} \mathrm{ha}{ }^{-1}$ $\left(\mathrm{RDCF}_{50 \%}+\mathrm{PM}_{1.5} \mathrm{tha}^{-1}\right)$ and $75 \% \mathrm{RDCF}+\mathrm{PM} 1 \mathrm{t} \mathrm{ha}^{-1}\left(\mathrm{RDCF}_{75 \%}+\mathrm{PM}_{1 \mathrm{tha}}{ }^{-1}\right)$. The experiment was laid out in a randomized complete block design with three replications. The unit plot size was $4.0 \mathrm{~m} \times 2.5 \mathrm{~m}$. The treatments were randomly distributed. At the time of final land preparation, the land was fertilized at rates of $55,160,110$ and $97 \mathrm{~kg} \mathrm{ha}^{-1}$ of urea, triple superphosphate, muriate of potash and gypsum, respectively. Cowdung and poultry manure was also used @ 10 and $3 \mathrm{t} \mathrm{ha}^{-1}$, respectively. Seeds were sown on 27 July, 2011. Weeding, gap filling, thinning, irrigation and pesticide application were done as and when necessary. Finally, plants were harvested and data on yield and yield contributing parameters were collected from crop samples. Grain yield and straw yield altogether were considered as biological yield. Harvest index denotes the ratio of grain yield to biological yield multiplied by 100 . The percentage of protein in seeds was calculated by multiplying the value of $\mathrm{N}$ by a factor 6.25 (Morrison, 1956). The oil content of soybean seed was determined by Floch method (Floch, 1957). Analysis of variance was done with the help of computer package program according to Gomez and Gomez (1984) and the mean differences among different treatments were adjudged by LSD test.

\section{Results and Discussion}

\section{Plant height}

Plant height at the harvesting stage varied significantly due to the application of cowdung, poultry manure and chemical fertilizer (Table 1). At harvest, the tallest plant $(47.77 \mathrm{~cm})$ was recorded from RDCF, which was statistically different from other treatments at $1 \%$ level of significance but identical with $\mathrm{RDCF}_{75 \%}+\mathrm{PM}_{1 \mathrm{tha}}{ }^{-1}$. The shortest plant was found in control, which was statistically identical with $\mathrm{CD}_{10}$ tha 1. This finding was similar with Navin et al. (1996). Falodun and Osaigbovo (2010) conducted an experiment and reported that the plant height was enhanced by organic and inorganic fertilizers.

\section{Total branches plant ${ }^{-1}$}

Total branches plant ${ }^{-1}$ was significantly influenced by different treatments (Table 1 ). The maximum number of branches plant ${ }^{-1}$ (4.67) was obtained in CF that was statistically identical with the treatment $\mathrm{RDCF}_{75 \%}+\mathrm{PM}_{1 \mathrm{tha}}{ }^{-1}$ and minimum was obtained in control. Falodun and Osaigbovo (2010) stated that total number of branches plant ${ }^{-1}$ was enhanced by organic and inorganic fertilizers. Patwary (2003) observed that application of $\mathrm{P}$ and $\mathrm{S}$ increased the branches plant $^{-1}$.

\section{Pods plant ${ }^{-1}$}

Different fertilizer treatments showed a significant effect on the number of pods plant $^{-1}$ (Table 1 ). Due to different treatments the number of pods plant ${ }^{-1}$ ranged from 12.8 to 21.0. The highest number of filled pod was recorded in RDCF that was statistically identical with the treatment $\mathrm{RDCF}_{75 \%}+\mathrm{PM}_{1 \mathrm{th}} \mathrm{h}^{-1}, \mathrm{RDCF}_{50 \%}+$ $\mathrm{PM}_{1.5 \mathrm{tha}}{ }^{-1}$ and $\mathrm{RDCF}_{75 \%}+\mathrm{CD}_{3 \mathrm{tha}}{ }^{-1}$. The lowest number of filled pods was observed in control, which was identical with treatment $\mathrm{RDCF}_{50 \%}, \mathrm{CD}_{10 \mathrm{tha}} \mathrm{g}^{-1}$. This finding was supported by Chaubey et al. (2000) who obtained significantly the highest number of pods plant ${ }^{-1}$ by applying $S @ 45 \mathrm{~kg} \mathrm{ha}^{-1}$ through gypsum in groundnut.

\section{Grain plant ${ }^{-1}$}

Variation in number of grain plant ${ }^{-1}$ was found significant due to different fertilization application (Table 1). Application of $\mathrm{RDCF}_{100 \%}$ produced the highest number of grain plant $^{-1}$ (52.25), which was statistically identical to $\mathrm{RDCF}_{75 \%}+\mathrm{PM}_{1} \mathrm{tha}^{-1}$. The lowest number of seeds plant ${ }^{-1}$ (25.65) was found in control. Pathwary (2003) found highest seed plant ${ }^{-1}$ of soybean in S and $P$ treated plant. 


\section{0-grain weight}

The treatment had significant effect on 100-grain weight (Table 1). The highest value of the 100-grain weight was found in $\mathrm{RDCF}_{100 \%}$ (12.64 g) which was identical with $\mathrm{RDCF}_{75 \%}+\mathrm{PM}_{1} \mathrm{t} \mathrm{ha}^{-1}(12.62 \mathrm{~g})$ and the lowest weight was observed in control $(10.20 \mathrm{~g})$ treatment.

Table 1. Effect of organic and inorganic fertilizers on the yield and yield attributes of soybean cv BINA soybean-2

\begin{tabular}{|c|c|c|c|c|c|c|c|}
\hline Treatment & $\begin{array}{l}\text { Plant } \\
\text { height } \\
(\mathrm{cm})\end{array}$ & $\begin{array}{c}\text { Branches } \\
\text { plant }^{-1} \\
\text { (No.) }\end{array}$ & $\left|\begin{array}{c}\text { Filled pods } \\
\text { plant }^{-1} \\
\text { (No.) }\end{array}\right|$ & $\begin{array}{l}\text { Grains } \\
\text { plant }^{-1} \\
\text { (No.) }\end{array}$ & $\begin{array}{l}\text { 100-grain } \\
\text { wt. (g) }\end{array}$ & $\begin{array}{l}\text { Grain yield } \\
\text { increase over } \\
\text { control (\%) }\end{array}$ & $\begin{array}{c}\text { Stover yield } \\
\text { increase over } \\
\text { control (\%) }\end{array}$ \\
\hline Control & 25.47 & 1.96 & 12.80 & 25.65 & 10.20 & - & - \\
\hline $\mathrm{RDCF}_{100 \%}$ & 47.77 & 4.67 & 21.00 & 52.25 & 12.64 & 41.81 & 35.39 \\
\hline $\mathrm{RDCF}_{50 \%}$ & 32.00 & 3.06 & 15.30 & 34.23 & 11.64 & 23.90 & 20.69 \\
\hline $\mathrm{CD}_{10 \mathrm{tha}^{-1}}$ & 34.33 & 3.23 & 16.90 & 42.75 & 12.41 & 26.63 & 23.07 \\
\hline $\mathrm{RDCF}_{50 \%}+\mathrm{CD}_{5} \mathrm{tha}^{-1}$ & 38.83 & 3.71 & 17.98 & 46.97 & 12.43 & 37.18 & 31.36 \\
\hline $\mathrm{RDCF}_{75 \%}+\mathrm{CD}_{3 \mathrm{tha}}{ }^{-1}$ & 41.16 & 4.10 & 18.60 & 48.11 & 12.50 & 38.07 & 31.63 \\
\hline $\mathrm{PM}_{3 \mathrm{tha}^{-1}}$ & 37.73 & 3.70 & 17.55 & 43.50 & 12.52 & 33.93 & 30.97 \\
\hline $\mathrm{RDCF}_{50 \%}+\mathrm{PM}_{1.5 \mathrm{tha}^{-1}}$ & 43.60 & 4.06 & 18.60 & 49.48 & 12.60 & 37.67 & 32.75 \\
\hline $\mathrm{RDCF}_{75 \%}+\mathrm{PM}_{1 \mathrm{tha}}{ }^{-1}$ & 45.70 & 4.20 & 19.50 & 50.32 & 12.62 & 39.30 & 34.20 \\
\hline LSD & 6.76 & 0.95 & 6.06 & 9.34 & 1.97 & - & - \\
\hline CV (\%) & 3.79 & 4.75 & 4.02 & 4.12 & 1.89 & - & - \\
\hline
\end{tabular}

Legend: RDCF= Recommended doses of chemical fertilizer, $\mathrm{CD}=$ Cowdung, $\mathrm{PM}=$ Poultry manure

\section{Grain yield}

Grain yield significantly varied among different treatments (Fig. 1). The grain yield ranged from 1570.27 to $2698.70 \mathrm{~kg} \mathrm{ha}^{-1}$ with different treatments. All the fertilizer treatments gave significantly higher grain yield over control. The highest grain yield $\left(2699 \mathrm{~kg} \mathrm{ha}^{-1}\right.$ ) was obtained in RDCF, which was statistically identical to $\mathrm{RDCF}_{75 \%}+\mathrm{PM}_{1 \mathrm{t} \mathrm{ha}}{ }^{-1}$ and the lowest grain yield $\left(1570.27 \mathrm{~kg} \mathrm{ha}^{-1}\right.$ ) was recorded from control. Poultry manure showed better performance in producing grain yield with respect to other organic manures. Yamika and Ikawati (2012) found that the combination of inorganic with organic fertilizers (0, 0.5 and $1 \mathrm{t} \mathrm{ha}^{-1}$ ) increased the seed yield up to $3.5 \mathrm{t} \mathrm{ha}^{-1}$. Mahesbabu et al. (2008) also observed that application of recommended dose of $\mathrm{N}$ : K: S with CD $5 \mathrm{t} \mathrm{ha}^{-1}$ produced grain yield $\left(2235 \mathrm{~kg} \mathrm{ha}^{-1}\right)$ which was closely similar to this experiment.

\section{Stover yield}

Application of different manures in combination with RDCF significantly influenced stover yield of soybean (Fig. 1). Similar to grain yield, all the fertilizer treatment gave significantly higher stover yield over the control. The stover yield due to different treatments ranged from 3010 to $4660 \mathrm{~kg} \mathrm{ha}^{-1}$. The highest stover yield (4660 kg ha') was obtained in the treatment $\mathrm{CF}_{75 \%}+\mathrm{PM}_{1} \mathrm{t} \mathrm{ha}^{-1}$ which was statistically identical to $\mathrm{RDCF}_{100 \%}$ but dissimilar to other treatments. The lowest stover yield (3010 kg ha ${ }^{-1}$ ) was recorded in the control treatment. The stover yield of soybean was maximum because poultry manure with chemical fertilizers added much of organic matter in soil, which influenced the vegetative growth of soybean plant. Dikshit and Khatik (2008) observed that application of organic and inorganic fertilizers increased the stover yield of soybean. Forhad and Malik (2010) also reported that application of P and K also increased the stover yield. Stover yield increased over control was the highest in $\mathrm{RDCF}_{100 \%}$. 


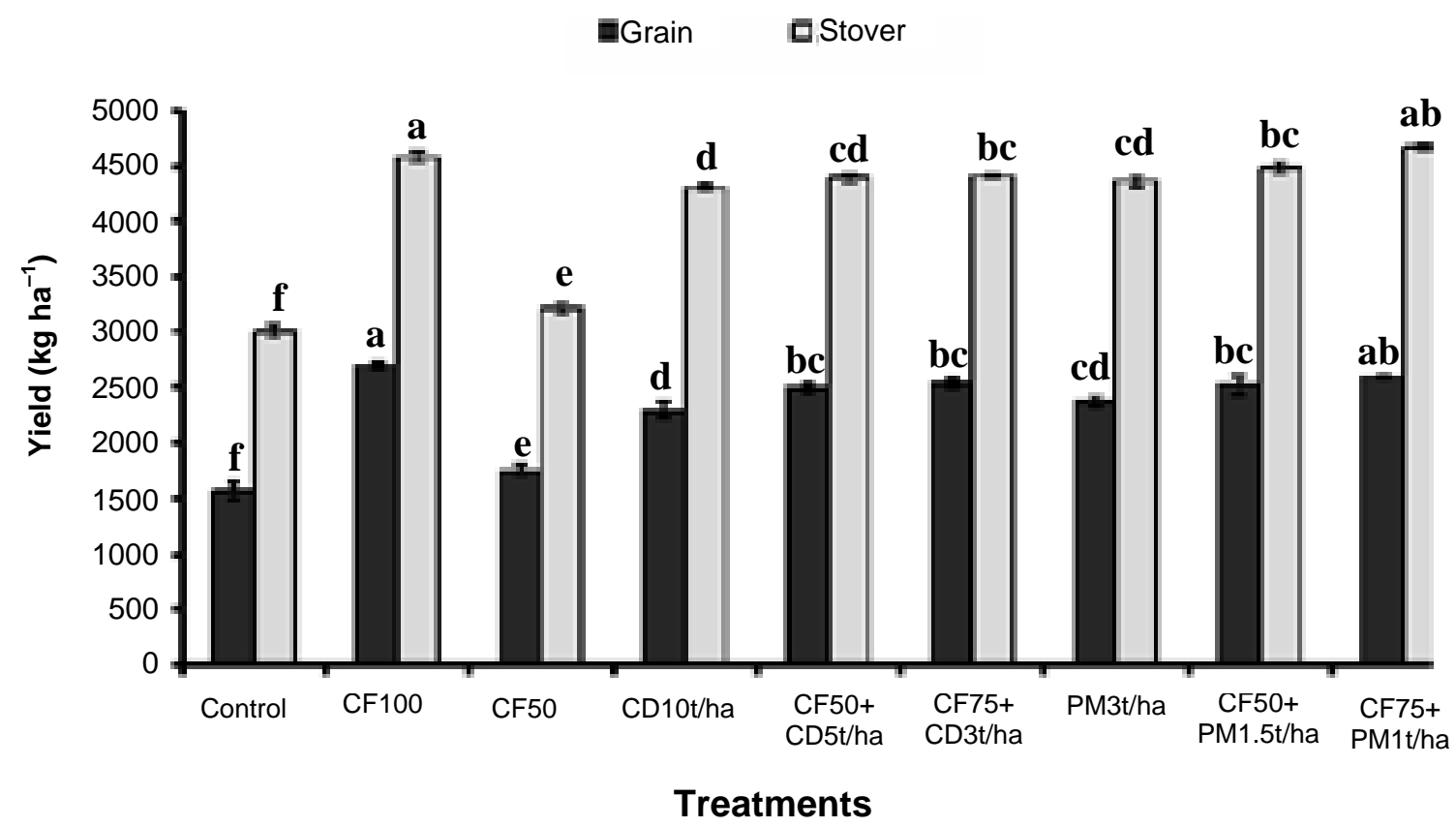

Fig. 1. Effect of organic and inorganic fertilizers on grain and stover yield of soybean cv. BINA soybean-2 (Bar indicates standard error)

\section{Biological yield}

It is evident from Fig. 2 that the biological yield was maximum at $\mathrm{RDCF}_{100 \%}\left(7373 \mathrm{~kg} \mathrm{ha}^{-1}\right)$ treatment and the lowest value was obtained from control $\left(4581 \mathrm{~kg} \mathrm{ha}^{-1}\right)$ treatment. From the result, it can be concluded that chemical fertilizer increased the biological yield which might be due to the cumulative favorable effect of grain and straw yield. Biological yield was also increased in the $\mathrm{RDCF}_{75 \%}+\mathrm{PM}_{1 \mathrm{tha}}{ }^{-1}$ and $\mathrm{CD}_{10} \mathrm{tha}^{-1}$ where poultry manure and cowdung were applied in decomposed form and they were identical the highest yield of RDCF ${ }_{100 \%}$. 


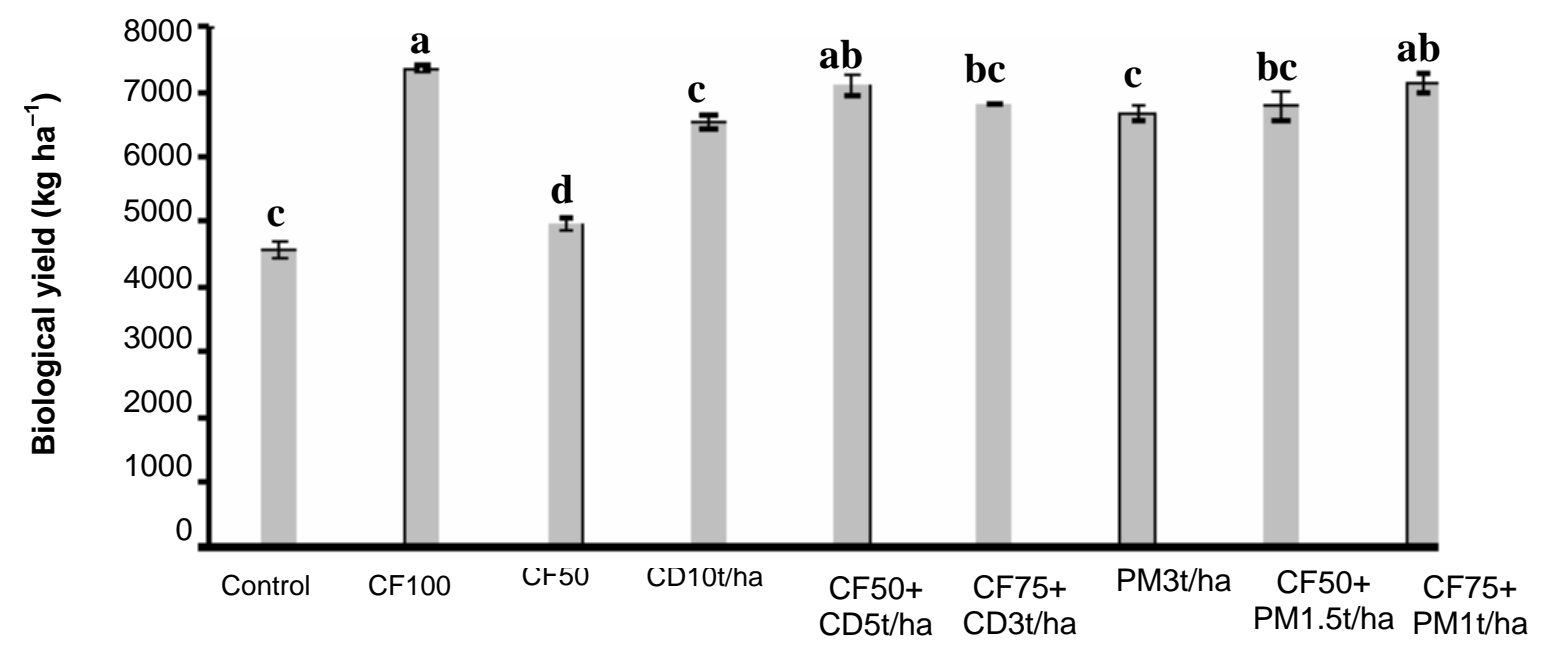

\section{Treatments}

Fig. 2. Effect of organic and inorganic fertilizers on biological yield of soybean cv. BINA soybean-2 (Bar indicates standard error)

\section{Harvest index}

Different fertilizers showed significant influence on harvest index. The highest harvest index was observed in $\mathrm{RDCF}_{100 \%}$ (37.09) treatment and the lowest value was observed in control (34.24) treatment (Table 2). The treatments $\mathrm{CD}_{10 \mathrm{tha}}{ }^{-1}, \mathrm{CF}_{75 \%}+\mathrm{CD}_{3 \mathrm{tha}}{ }^{-1}, \mathrm{PM}_{3 \mathrm{tha}}{ }^{-1}, \mathrm{RDCF}_{50 \%}+\mathrm{PM}_{1.5 \mathrm{tha}}{ }^{-1}$ and $\mathrm{RDCF}_{75 \%}+\mathrm{PM}_{1 \mathrm{t}}$ $\mathrm{ha}^{-1}$ showed the statistically identical harvest index. It is evident from the results that harvest index was influenced by the application of chemical fertilizer with other fertilizers. This might be due to RDCF and other organic fertilizers, which affected the biological yield and grain yield.

\section{Protein content}

Seed protein content was directly influenced by the $\mathrm{N}$ and $\mathrm{S}$ contents. The highest protein content (45.73\%) was obtained when chemical fertilizer was applied at the recommended doses containing $\mathrm{N}$ and $\mathrm{S}$ in the form urea @ $55 \mathrm{~kg} \mathrm{~N} \mathrm{ha}^{-1}$ and gypsum @ $97 \mathrm{~kg} \mathrm{ha}^{-1}$,which was also identical to $\mathrm{RDCF}_{50 \%}+\mathrm{PM}_{1.5} \mathrm{tha}^{-1}$ and $\mathrm{RDCF}_{75 \%}+\mathrm{PM}_{1 \mathrm{tha}}{ }^{-1}$ and the lowest content (40.12\%) was from control (Table 2). It is evident from the results that $\mathrm{N}$ and $\mathrm{S}$ had remarkable influence on protein content. Because both the nutrients are required for the synthesis of amino acids especially $S$ for cystine, cysteine and methionine which are essential components of protein (Tisdale et al., 1999). The above findings were in agreement with the results of Sharma et al. (2002), who reported that protein yield was increased with increased rate of S. Sahoo et al. (2000) also found that protein content increased significantly with higher $\mathrm{N}$ rates. Similar opinion was on put forward by Babhulkar et al. (2000) in safflower. On the other hand, Ali et al. (1997) found that S decreased protein content and increased oil content.

\section{Oil content}

There was no significant effect of different fertilizers on the oil content of soybean (Table 2). It was observed that the oil content of soybean was increased with the application of $\mathrm{RDCF}_{100 \%}(21.0 \%)$ and the lowest content was found in control $(20.25 \%)$ treatment. The highest oil content $(21.0 \%)$ was found in chemical fertilizer. This might be due to the chemical fertilizers where sulphur was applied in the form of gypsum. Application of $S$ promoted seed oil content due to increasing uptake of $S$ elements by plants which brought to increase $S$ bearing fatty acids. The present result was consistent with that of Babhulkar et al. (2000), who reported that increases in levels of $S$ increased the oil content. Similar finding was also recorded by Ganeshmurthy (1996) in Soybean and Yadav et al. (1996) in sesame. 
Table 2. Effect of organic and inorganic fertilizers on harvest index, protein and oil content of soybean cv. BINA soybean-2

\begin{tabular}{|l|c|c|c|}
\hline \multicolumn{1}{|c|}{ Treatments } & Harvest index (\%) & Protein (\%) & Oil (\%) \\
\hline Control & 34.24 & 40.12 & 20.25 \\
\hline $\mathrm{RDCF}_{100 \%}$ & 37.09 & 45.73 & 21.00 \\
\hline $\mathrm{RDCF}_{50 \%}$ & 35.3 & 42.12 & 20.32 \\
\hline $\mathrm{CD}_{10 \mathrm{tha}}{ }^{-1}$ & 35.58 & 42.98 & 20.15 \\
\hline $\mathrm{RDCF}_{50 \%}+\mathrm{CD}_{5 \mathrm{tha}^{-1}}{ }^{-1}$ & 35.11 & 43.90 & 20.50 \\
\hline $\mathrm{RDCF}_{75 \%}+\mathrm{CD}_{3 \mathrm{tha}^{-1}}$ & 36.69 & 44.00 & 20.90 \\
\hline $\mathrm{PM}_{3 \mathrm{tha}}^{-1}$ & 35.69 & 43.00 & 20.70 \\
\hline $\mathrm{RDCF}_{50 \%}+\mathrm{PM}_{1.5 \mathrm{tha}^{-1}}{ }^{-1}$ & 36.24 & 44.68 & 20.85 \\
\hline $\mathrm{RDCF}$ & & 20.98 \\
\hline $\mathrm{LSD}$ & 35.69 & 45.00 & 1.36 \\
\hline $\mathrm{CV}(\%)$ & 1.29 & 1.27 & 3.96 \\
\hline
\end{tabular}

Legend: $\mathrm{RDCF}=$ Recommended doses of chemical fertilizer, CD = Cowdung, PM = Poultry manure

\section{References}

Ali, M. H. and Zaman, S. M. H. 1997. Dry matter accumulation, nutrient uptake and seed yield of rape-seed (Brassica Camprestris) as affected by population density and fertilizers. Indian J. Agric. Sci. 67(1): 23-60.

Babhulkar, P.S., Badole, W.P., Balapnde, S.S and Kar, D. 2000. Effect of sulphur and zinc on yield, quality and nutrient uptake by safflower in versitol. J. Indian Soc. Soil Sci. 48(3): 541-543.

Chaubey, A.K., Singh, S.B. and Kaushik, M.K. 2000. Response of groundnut to source and level of sulphur fertilizer in mid western plains of Uttar Pradesh. Indian J. Agron. 45(1): 166-169.

Dikshit, P.R. and Khatik, S.K. 2008. Influence of organic manures in combination with chemical fertilizers on seed yield. Legume Res. 25(1): 53-56.

Falodun, E.J. and Osaigbovo, A.U. 2010. The effect of packaged organic and inorganic fertilizers on the growth and yield of soyabean (Glycine max). African J. Agric. 25(1): 34-37

Folch, J., Less, M. and Stone Stanley, G.H. 1957. A simple method for the isolation and purification of total lipids from animal tissues. J. Biol. Chem. 226: 497-508.

Forhad, M. and Malik, S. 2010. Role of potassium and sulphur on the growth, yield and oil content of soybean (Glycine max L.). J. Plant Sci. 3 (2): 99-103.

Ganeshamurthy, A.N. 1996. Critical plant sulphur content and effect of sulphur application on grain and oil yield of rainfed soybean in vertic ustochrepts. J. Indian Soc. Soil Sci. 44 (2): 290-294.

Gomez, K.A. and Gomez, A.K. 1984. Statistical Procedures for Agricultural Research. $2^{\text {nd }}$ edn. John Wiley and Sons. New York. pp. 207-215.

Gopalan, C., Sastri, R.B.V. and Balasubramanian, S.C. 1971. Nutritive value of Indian Foods. ICMR. 16 (2): 62-63.

Kaul, A.K. and Das, M.L. 1986. Oil seed in Bangladesh. Ministry of Agriculture. Dhaka.

Maheshbabu, H.M., Hunje, R. and Patil, N.K. 2008. Effect of organic manures on plant growth, seed yield and quality of soybean. Karnataka J. Agric. Sci. 21 (2): 219-221.

Morrison, F.B. 1956. Feeds and Feeding. $22^{\text {th }}$ edn. The Morrison Publishing Company, Ithaca, New York. USA. p. 77.

Navin, K., Singh, V.K. Thakur, R.B and Kumar, N 1996. Effect of level and time of N application on the performance of winter rice. J. Applied Biol. 6 (1-2): 48-53.

Page, A.L., Miller, R. H. and Keeney, D.R. (eds).1982. Methods of Soil Analysis. Part-II. $2^{\text {nd }}$ edn. Amer. Soc. Agron. Inc. Madison, Washington, USA.

Patwary, M.O.F. 2003. Effect of sulphur and phosphorus on the yield, yield attributes and quality of soybean cv. Shohag (PB-1). M.S. Thesis. Dept of Agric. Chemistry. Bangladesh Agricultural University, Bangladesh.

Rahman, L. 1982 Cultivation of soybean and its uses. Citypress. Dhaka. pp. 5-7.

Sahoo, S.K., Mitra, G.N. and Brar, M.S. 2000. Effect of spacing regimes and N levels on seed yield and quality of mustard. Indian J. Agron. 42(4): 650-652.

Sharma, R.K., Singh, V., Chauhan, S. and Sharma, R.A. 2002. Studies on influence of various levels and source of sulphur on seed yield and biochemical composition of soybean. J. Res. Crops. 2(3):317-319.

Shirpukar, G.N., Kashid, N.V., Kamble, M.S., Pisal, A.A. and Sarode, N.D. 2006. Effect of application of Zn, B and Mo on the yield and yield attibuting characters of soybean. Legume Res. 29 (4): 242-246.

Tisdale, L.S., Nelson, L.N Beaton, D.J. and Havlin, L.J. 1999. Soil Fertility and Fertilizers. Macmillan. $6^{\text {th }}$ edn. p. 220.

Yadav, N.P.S.; Mehta, V.S. and Singh, V. 1996. Effect of different levels on source of sulphur on yield, quality and uptake of sulphur by sesame. J. Oilseeds Res.13 (1): 22-25.

Yamika, W.S.D. and Ikawati, K.R. 2012. Combination inorganic and organic fertilizer increased yield production of soybean. American-Eurasian J. Sustainable Agric. 6(1): 14-17. 